\title{
Microscopy and Microanalysis of Magmatic and Metamorphic Minerals-Part 2: Feldspar
}

\author{
Robert Sturm
}

Brunnleitenweg 41, A-5061 Elsbethen, Salzburg/Austria

Robert.Sturm@sbg.ac.at

\section{Introduction}

Feldspar is the name for a mineral group consisting of nearly 20 triclinic or monoclinic mineral species, of which only nine are well documented and widely distributed in the Earth's crust. Single members of the feldspar group belong to the so-called framework-or tectosilicates, where $\mathrm{SiO}_{4^{-}}$ and $\mathrm{AlO}_{4}$-tetrahedra share all their oxygen ions, resulting in an infinite three-dimensional network [1]. Feldspar crystals include the major elements $\mathrm{K}, \mathrm{Na}, \mathrm{Ca}, \mathrm{Al}$, as well as $\mathrm{Si}$ and thus may be attributed to one of the following three endmembers: potassium-feldspar (K-feldspar) $\mathrm{KAlSi}_{3} \mathrm{O}_{8}$, albite $\mathrm{NaAlSi}_{3} \mathrm{O}_{8}$, or anorthite $\mathrm{CaAl}_{2} \mathrm{Si}_{2} \mathrm{O}_{8}$ (Table 1). Solid solutions occur between K-feldspar and albite, forming what is commonly known as alkali feldspar, and between albite and anorthite, forming plagioclase. The alkali feldspar group consists of orthoclase, microcline, sanidine, and anorthoclase, whereas the plagioclase group includes albite, oligoclase, andesine, labradorite, bytownite, and anorthite [2].

An interesting question concerns the natural occurrence of feldspar. Minerals belonging to this group chiefly crystallize

Table 1: Chemical composition and physical properties of the feldspar group.

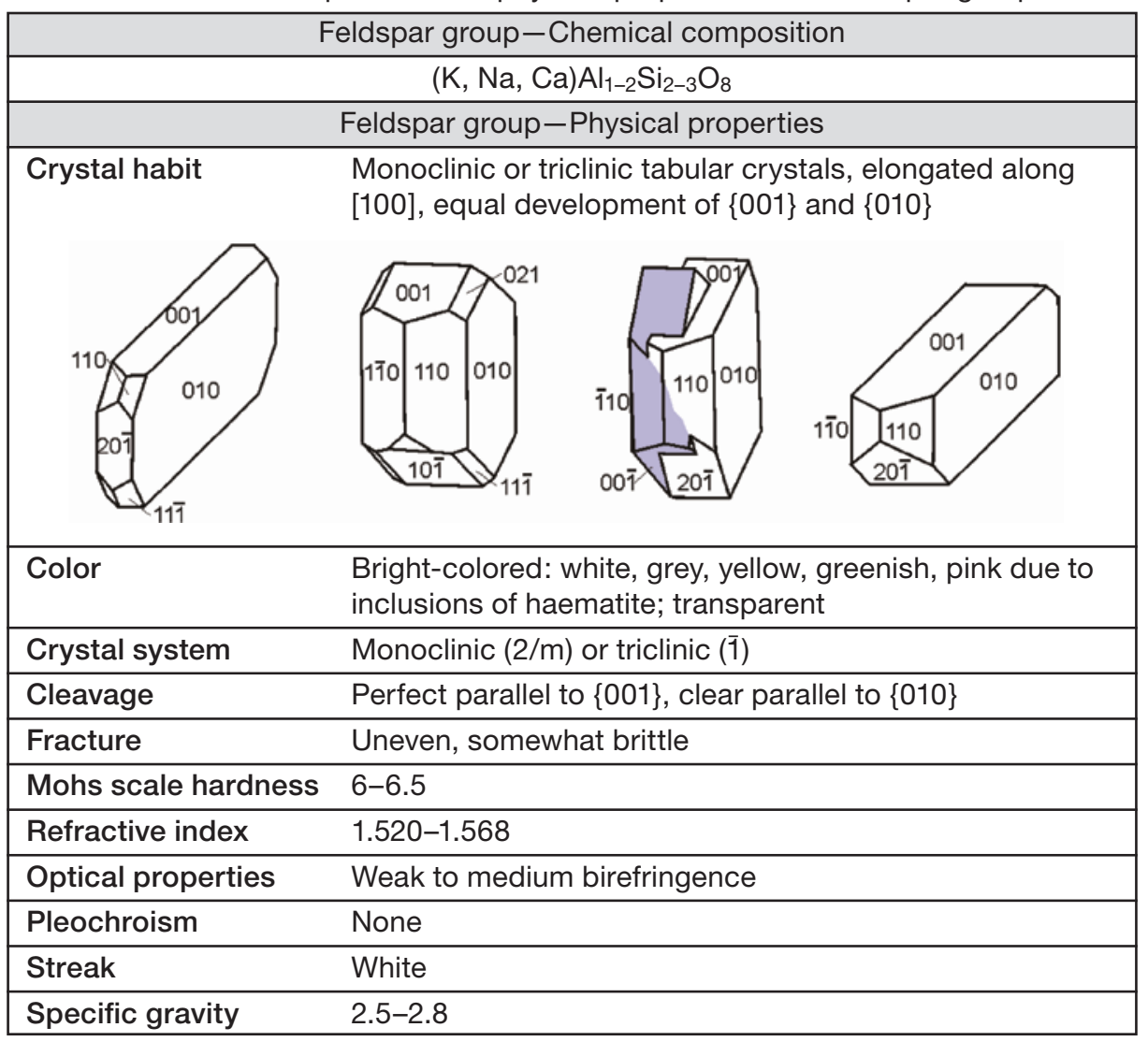

from magmatic sources of both intrusive (plutonic) and extrusive (vulcanic) igneous rocks [1]. In most of these rocks feldspar represents a major constituent with a volume portion ranging from 30 to $50 \%$. If feldspar-bearing igneous rocks are subject to an extensive physical weathering, sediments may be formed that contain a significant amount of the feldspar phase. However, such feldspar sediments and sediment rocks (arkose) are quite rare because in most environments feldspar has a remarkable tendency to be altered to other substances such as clay minerals [3]. A further important source of the feldspar group is metamorphic rocks, which were formed from precursor rocks containing feldspar minerals and/or all those major elements required for their crystallization. Although anorthite and orthoclase are commonly found in mediumto high-grade metamorphic gneisses and schists, albite and oligoclase mainly crystallize in low- to medium-grade metamorphites. An interesting metamorphic occurrence may be attested to the mineral sanidine, whose preferential formation takes place under conditions of high-temperature contact metamorphism [3]. Finally, feldspar minerals occur in pegmatites and veins where they crystallize from fluids containing all source elements necessary for their formation. In the case of slow continuous crystal growth, minerals may reach sizes of several centimetres [1].

In the present contribution, the microscopic and microchemical characteristics of feldspar are introduced to microscopists interested in mineralogy. The detailed description of the mineral is conducted using samples from igneous and metamorphic rocks exposed at the southwestern margin of the Bohemian Massif in Austria (see geological map in Figure 1).

\section{Microscopy and Microanalysis of Feldspar}

One part of each rock sample taken at a predefined location within the Bohemian Massif was used for the production of thin sections that served for light microscopy (Figure 2). Respective investigations were conducted on a petrographic microscope (ZEISS POLYVAR), appropriately equipped for bright- and dark-field microscopy. In addition to the petrographic thin sections, polished 


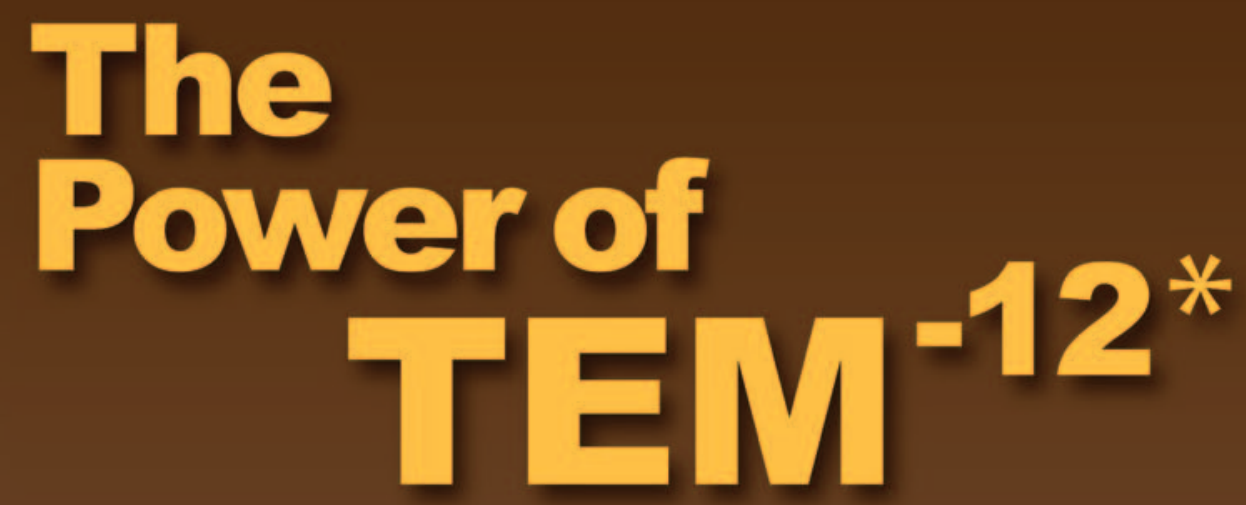

The best atomic level

Seeing is believing.

jeolusa.com/ARM200F

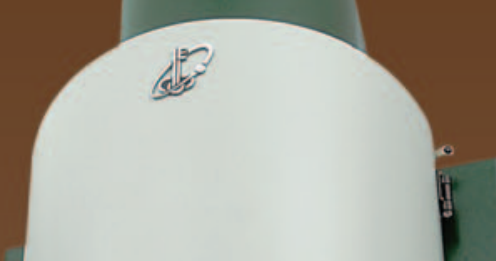

\section{imaging and chemical mapping available today.}
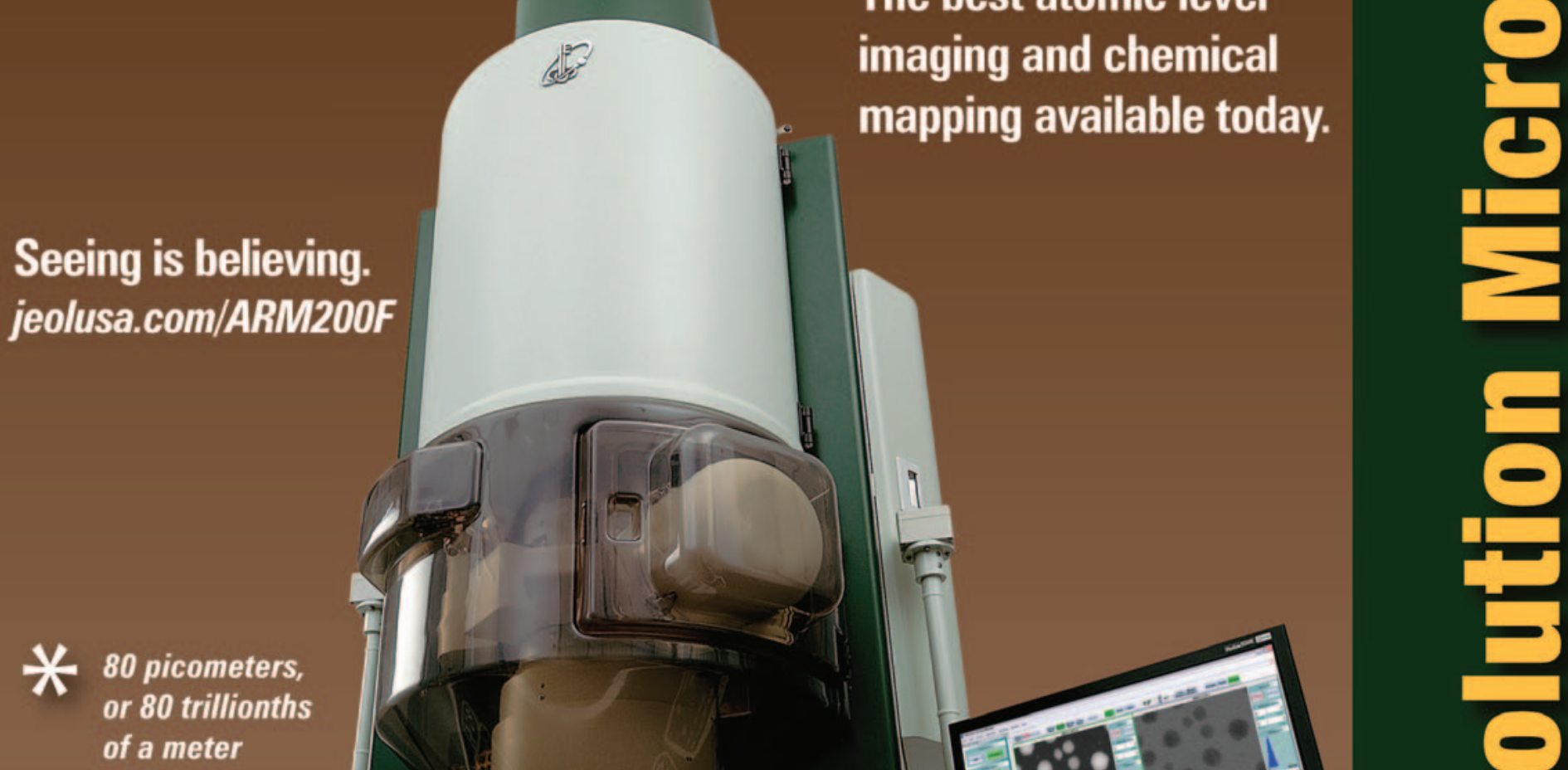
or $\mathbf{8 0}$ trillionths of a meter
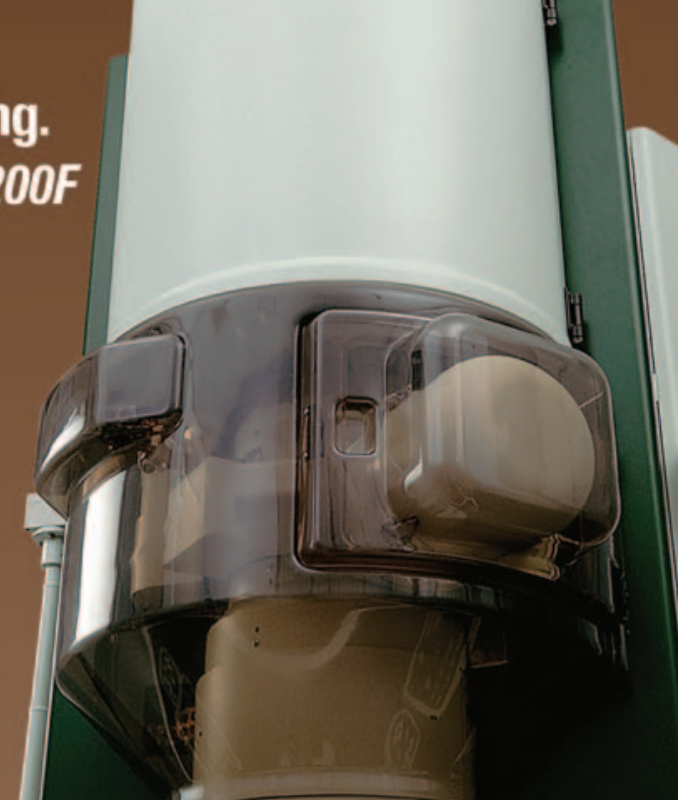
a

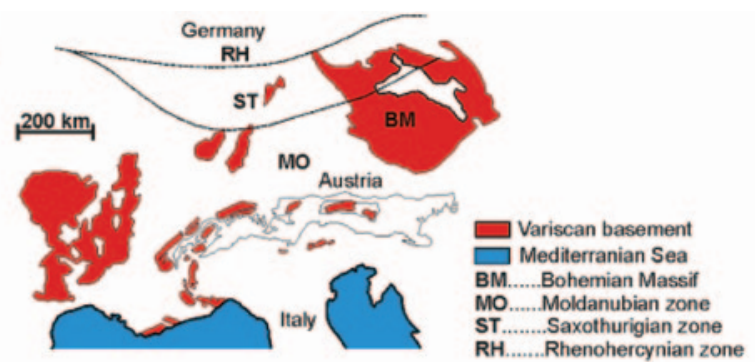

b

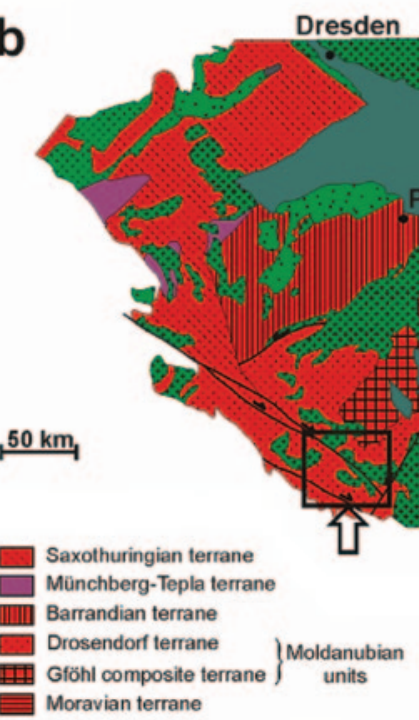

Figure 1: Geological map illustrating the position of the sample rocks within the Bohemian Massif. a) Sketch of central Europe providing an overview of the geographic position of the Variscan basement. b) Geological detail map of the Bohemian Massif with its main tectonometamorphic units. Square and arrow indicate the position of the study area.

bulk specimens were used for microchemical investigations and backscattered electron imaging (BSEI). Both procedures were carried out on a JEOL JXA-8600 microprobe at the former Institute of Geology, University of Salzburg. The main operating parameters were as follows: 30 -nA beam current, $15-\mathrm{kV}$ accelerating voltage, 10 -second counting time for each element except $\mathrm{Na}(30 \mathrm{~s})$, and a constant beam diameter of $1 \mu \mathrm{m}$. Wavelength-dispersive spectrometer (WDS) crystals used for elemental analysis included lithium fluoride (LiF), pentaerythritol (PET), and thallium acid phthalate (TAP). Natural and synthetic silicates as well as oxides served as standards for the main element analyses [4]. Correction of the raw analyses was carried out by the application of an system-internal ZAF-4 procedure provided by JEOL. The average calculated precision of the standardized element analyses was on the order of 0.1 wt. \%.

\section{Rock Samples Containing Feldspar Minerals from the Bohemian Massif}

Rock samples used here for the investigation of feldspars are from the exposed south-western margin of the so-called Bohemian Massif (Figure 1b), a huge Variscan mountain belt that can be assigned to the central-European Moldanubian zone. Within this large-scale tectonometamorphic unit, widespread high-temperature/low-pressure metamorphism, as well as partial melting processes (anatexis) and extensive
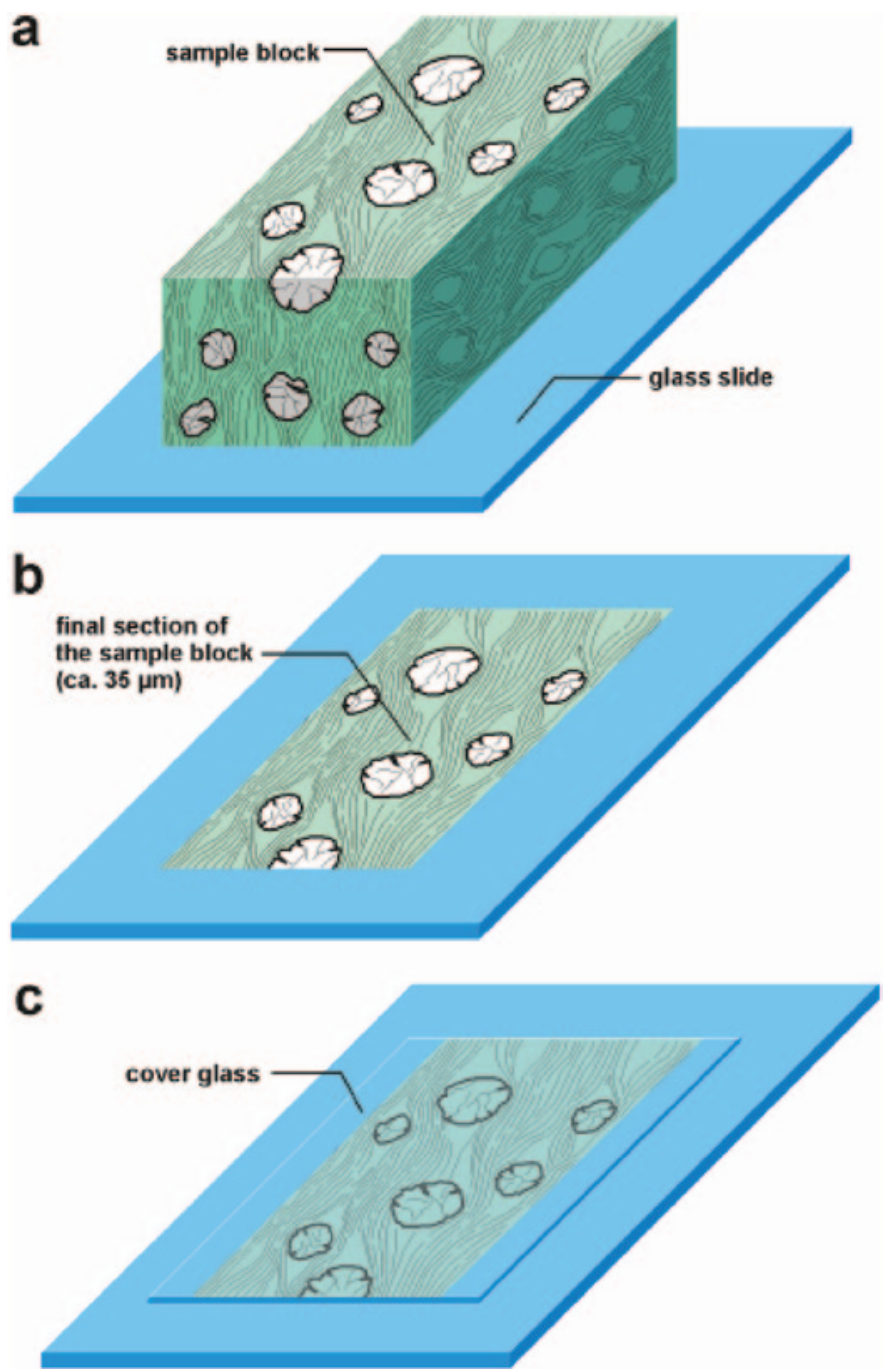

Figure 2: Steps for the preparation of petrographic thin sections used for light microscopy. a) Fixation of the sample block on the glass slide. b) Grinding and polishing of the sample block until a final thickness of ca. $35 \mu \mathrm{m}$ is reached. c) Covering of the thin section with Canada balsam and a thin cover glass. Polished thin sections used for EMPA are made in a very similar way. Instead of covering the surface of the section, a final polishing process is carried out producing a perfect section plane.

plutonism, form the geology of the study area. The sample rocks belong to the Variscan migmatites and gneisses of the so-called Monotonous series, a part of the Drosendorf terrane (Figure 1b) and to those Variscan and post-Variscan granite bodies that have intruded the nappes of the Monotonous series [5].

Pearl gneiss (Sample no. 1, Figures $3 \mathrm{~b}$ and $3 \mathrm{~d}$ ), a dark rock rich in biotite, exhibits highly variable percentages of the major mineral constituents (plagioclase, biotite, K-feldspar, quartz, and cordierite). Plagioclase (oligoclase) represents the most impressive mineral phase because of its macroscopic appearance as white pearl- or pill-shaped crystals with diameters up to $1 \mathrm{~cm}$.

Coarse-grained gneiss (Sample no. 2, Figure 3c) is also characterized by an enhanced plagioclase content (up to 40 vol. \%) forming irregularly shaped aggregates ("Schlieren") and layers in the rock. Further mineral constituents include K-feldspar, quartz, and biotite. 

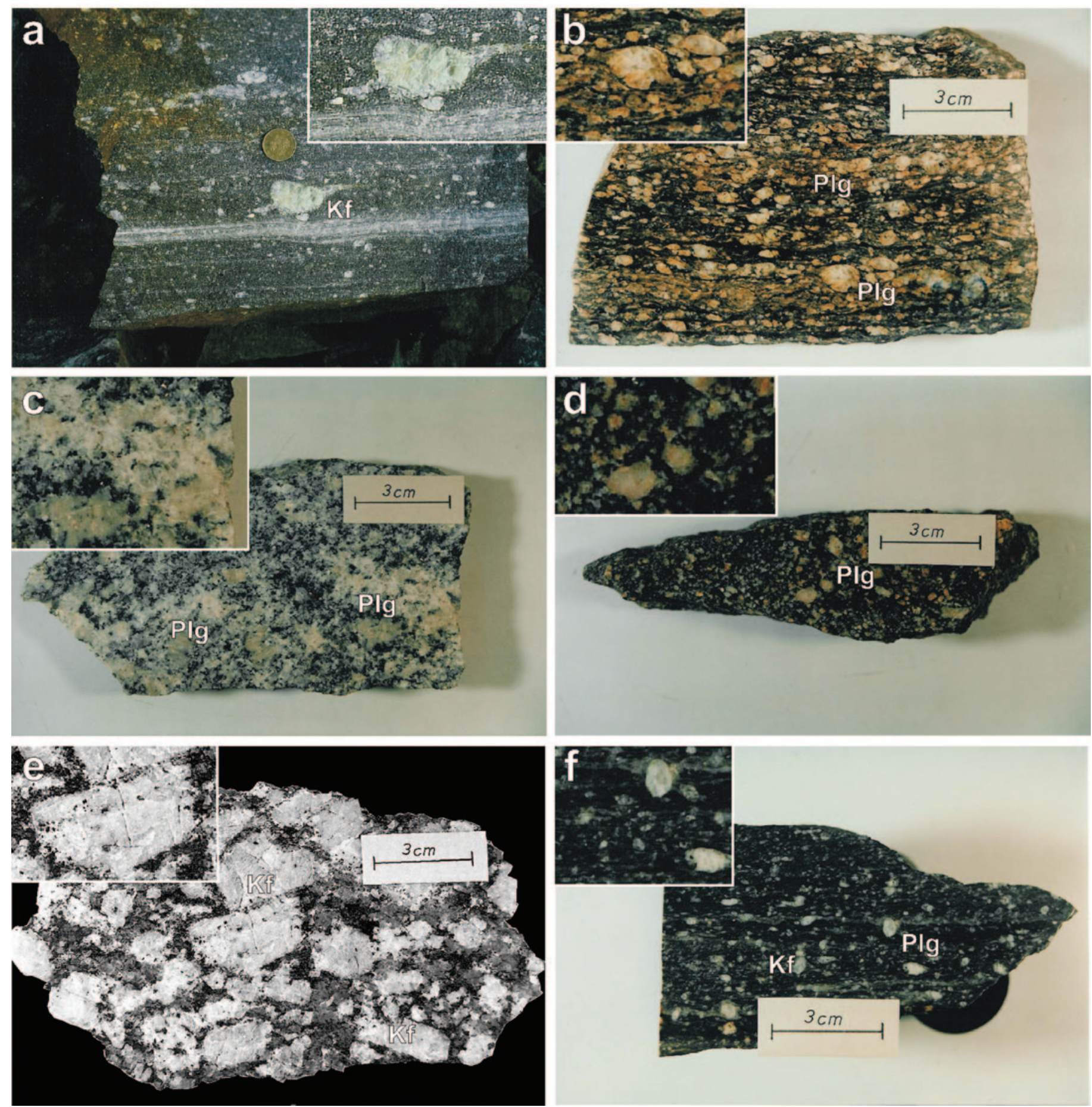

Figure 3: Igneous rocks sampled for the investigation of feldspar: (a) and (f) ultramylonite, (b) and (d) pearl gneiss, (c) coarse grained gneiss, (e) Weinsberg granite. As can be already recognized from the images, macroscopic appearance of feldspar ( $\mathrm{Kf}=\mathrm{K}$-feldspar, $\mathrm{Plg}=$ plagioclase $)$ is subject to high variability concerning the size and shape of single crystals.

Weinsberg granite (Sample no. 3, Figure 3e) is a rock within which K-feldspar occurs as large tabular crystals with variable idiomorphy and respective diameters ranging from 1 to $10 \mathrm{~cm}$. The matrix surrounding the feldspar grains is composed of quarz, biotite, and negligible amounts of plagioclase.

Ultramylonite (Sample no. 4, Figures $3 \mathrm{a}$ and $3 \mathrm{f}$ ) was introduced in part I of this investigation [4] as a fine-grained metamorphite containing equal amounts of plagioclase and
$\mathrm{K}$-feldspar clasts (up to $3 \mathrm{~cm}$ in diameter). It also contains quartz, biotite, and a considerable volume portion of cordierite.

\section{Microscopy and Microanalysis of Feldspar Crystals}

Light microscopy. Under the microscope, feldspar crystals are easy to recognize and to distinguish from other mineral phases because of the following: First, the grains are frequently characterized by their appearance as large clasts embedded in 
a fine matrix of minerals that were formed from the magma during later stages of crystallization or from metamorphic fluids by recrystallization processes (Figures 4,5 ). Second, feldspar grains may exhibit individual types of twinning that can be only observed in dark-field (crossed nicols). Therefore, plagioclase is marked by a so-called polysynthetic twinning, forming with a sequence of dark and bright stripes (Figures $4 a, 4 b, 5 c$ ). The K-feldspar phase (orthoclase) also may be twinned (Figure $5 \mathrm{~d})$, but in most cases appears as a homogeneously colored
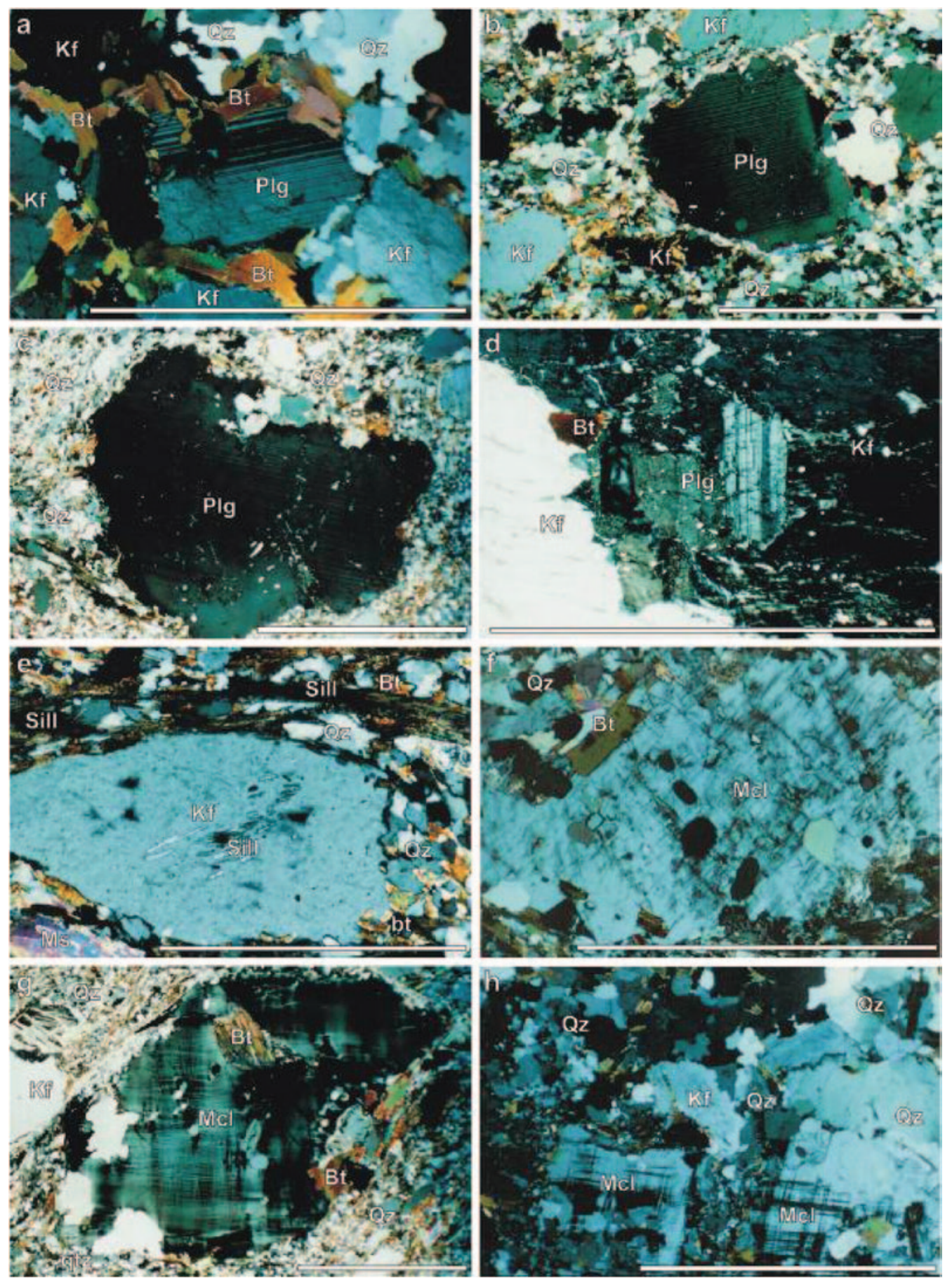

Figure 4: Appearance of feldspar under the light microscope: (a) coarse-grained gneiss; (b), (c), and (e) ultramylonite; (d) and (f) Weinsberg granite; (g) and (h) pearl gneiss. Bars indicate a length of $1 \mathrm{~mm}$, respectively. Abbreviations: $\mathrm{Bt}=$ biotite, $\mathrm{Kf}=\mathrm{K}$-feldspar, $\mathrm{Mcl}=$ microcline, $\mathrm{Plg}=$ plagioclase, $\mathrm{Qz}=$ quartz, Sill = sillimanite. mineral under the microscope. A remarkable exception from this role may be noted for the alkali-feldspar microcline (Figures $4 \mathrm{f}-4 \mathrm{~h}$ ) that has a very typical appearance in dark-field known as "microcline lattice" (Figures $4 \mathrm{f}-4 \mathrm{~h}$ ). The grains are subdivided into bands of dark and bright zones. Third, feldspar crystals frequently contain a high quantity of mineral inclusions, whereby the number of included phases is positively correlated with the size of the host minerals (Figures $4 \mathrm{~d}-4 \mathrm{~g}$ ). The so-called primary mineral inclusions are formed during the crystallization of the host minerals from the magma, whereas the secondary mineral inclusions are formed in the fully crystallized host phases during alteration processes. Primary mineral inclusions are important for the determination of mineral crystallization sequences in different magma types. In the case presented here, feldspar mainly includes quartz, biotite, other feldspar (Figure 4d), and accessory minerals such as zircon, rutile, titanite, and ilmenite. Secondaryinclusions are mainly represented by sillimanite (fibrolite, Figure 4e) and garnet, which both are formed under conditions of high-temperature metamorphism.

Compositional analysis. Electron microprobe analysis of feldspar crystals shows similar chemical compositions among the different feldspar types (Samples 1-4 in Table 2). Hence, K-feldspar is commonly characterized by $\mathrm{SiO}_{2}$ concentrations varying between 64 and $66 \%, \mathrm{Al}_{2} \mathrm{O}_{3}$ contents ranging from 16 to $19 \%, \mathrm{~K}_{2} \mathrm{O}$ contents ranging from 15 to $16 \%$ and $\mathrm{Na}_{2} \mathrm{O}$ concentrations being on the order of 0.6 to $0.9 \%$. The content of $\mathrm{CaO}$ may be considered negligible in most cases. This chemistry results in a clear predominance of the orthoclase component (90-93\%), followed by albite $(6-8 \%)$, and anorthite (0.1-1\%). K-feldspar from the Weinsberg granite (Sample 3) sometimes shows an enhanced content of $\mathrm{Na}_{2} \mathrm{O}$ (up to $7.5 \%$ ) at the cost of $\mathrm{K}_{2} \mathrm{O}$ (Table 2), resulting in a significant shift of the composition towards the albite component. For 

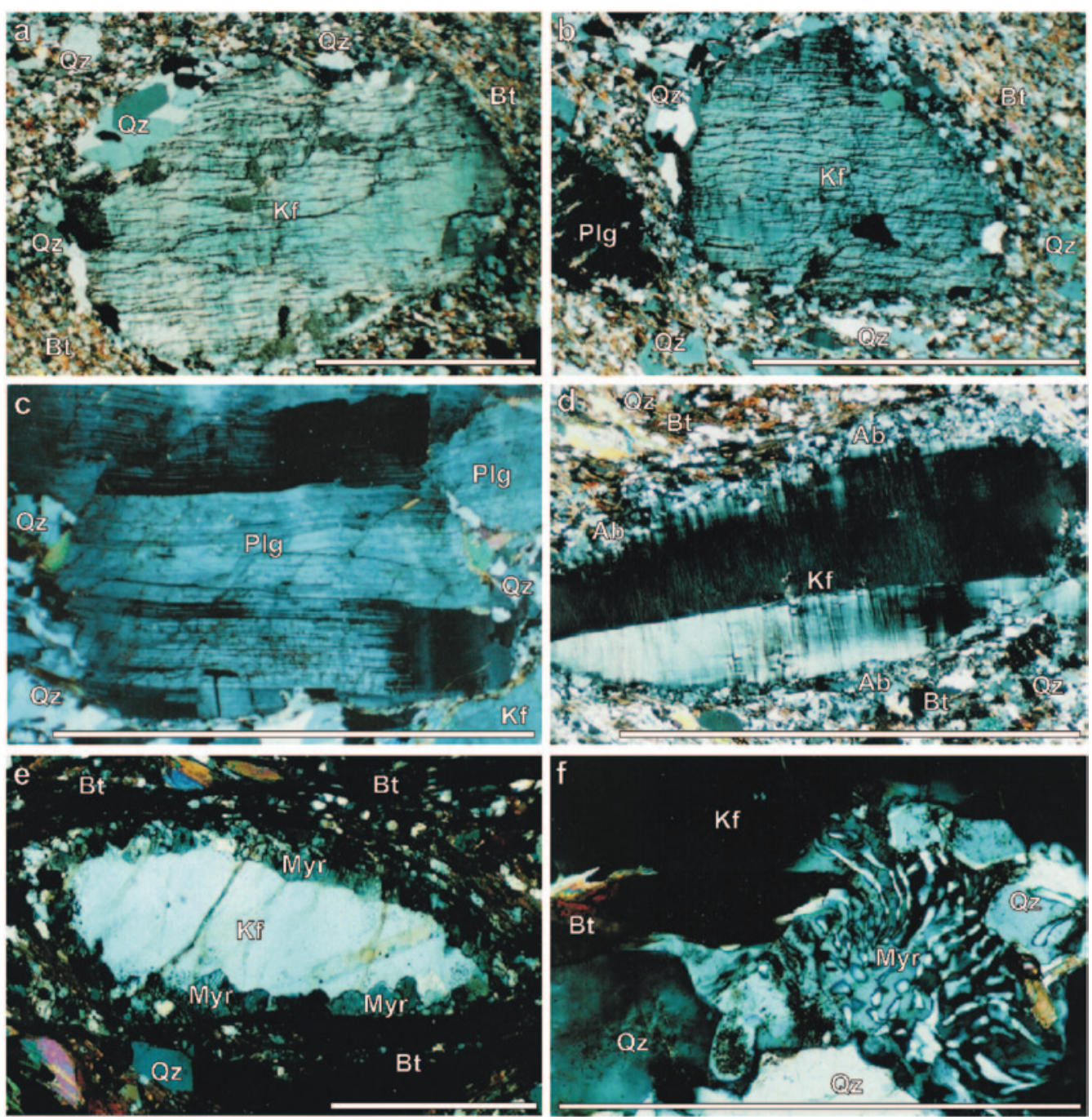

Figure 5: Mechanical deformation, high-grade metamorphic alteration, and retrograde de-composition of feldspar, photographically documented for the exemplary case of the ultramylonite, which was formed at a temperature of ca. $600^{\circ} \mathrm{C}$ and a lithological pressure of ca. 3.5 GPa. (a) and (b) show brittle deformation of feldspar with formation of cracks, (c) plastic deformation of plagioclase, (d) high-grade metamorphic core-mantle texture, and (e) and (f) retrograde myrmekite (Myr) formation according to equation (1) (see text). sillimanite (Sill in Figure 4d) and garnet. In specific cases so-called core-mantle textures like that depicted in Figure 5d were produced where the rim of a large K-feldspar clast is transformed into aggregates of small recrystallized grains. Besides a chemical alteration based on extensive processes of element diffusion and transport offluid phases, significant effects of mechanical influences on feldspar clasts may be observed in the rock samples of the ultramylonite. These mechanical forces are mainly expressed by cracks and fractures systematically running all over several grains (Figures 5a, 5b) or even by plastic deformations of single crystals (Figure 5c), resulting in their undulatory bending.

Under retrograde metamorphic conditions, which are marked by a continuous decline of temperature and lithological pressure, $\mathrm{K}$-feldspar is partly affected by a specific decomp-osition reaction resulting in the formation of fine (symplectitic) quartz and albite. This so-called myrmekite texture is usually produced at temperatures $\leq 500{ }^{\circ} \mathrm{C}$ and may be expressed by the following chemical reaction [7]: plagioclase, the concentration of $\mathrm{SiO}_{2}$ is usually less than that in $\mathrm{K}$-feldspar (61-63\%), whereas the content of $\mathrm{Al}_{2} \mathrm{O}_{3}$ is increased (23-25\%). The $\mathrm{CaO}$ content varies between 4 and $5 \%, \mathrm{~K}_{2} \mathrm{O}$ shows a concentration of 0.2 to $0.4 \%$, and the concentration of $\mathrm{Na}_{2} \mathrm{O}$ ranges from 8 to $9 \%$ (Table 2). This chemistry leads to a considerable predominance of the albite component (74-76\%), followed by anorthite (23-24\%), and orthoclase (1-2\%). Although these analyses are specific for the rocks introduced here, they may be also evaluated as representatives for single feldspar groups [1].

\section{Metamorphic Alteration and Retrograde Decomposition of Feldspar}

High-grade metamorphic alteration of feldspar was studied in the ultramylonite (Sample 4). As determined by the garnet-cordierite $\mathrm{Fe} / \mathrm{Mg}$-exchange thermometer, this rock was subject to a ductile deformation that took place at temperatures of about $600{ }^{\circ} \mathrm{C}$ and lithological pressures of about $0.30-0.40 \mathrm{GPa}[6]$. At the peak conditions of the metamorphic event, feldspar of the protolithic rock was involved in several alteration processes including the formation of fibrolitic

$$
\begin{array}{r}
\text { K-feldspar + sillimanite (kyanite) }+\mathrm{H}_{2} \mathrm{O} \\
\rightarrow \text { plagioclase }+ \text { quartz }+ \text { muscovite }
\end{array}
$$

In general two types of myrmekite textures may be distinguished, that is, the bulbous myrmekite with the symplectitic texture directly intruding into the adjacent K-feldspar (Figure 5f) and the corona-like myrmekite, where the decomposited feldspar is perfectly surrounded by a corona of the symplectitic texture (Myr in Figure 5e). In the latter case, quartz and albite are increasingly accompanied by muscovite. The second type of myrmekite texture preferentially occurs at the edge of feldspar crystals that are subject to increased deformational forces [7].

\section{Conclusion}

Feldspar with its structural and chemical variations represents a ubiquitous mineral phase occurring in many different types of igneous and metamorphic rocks. The mineral group is an interesting study object for microscopists because of its characteristic appearance in petrographic thin sections. Whereas plagioclase exhibits a so-called polysynthetic twinning 
Table 2: Results of microchemical analysis (wt\%) of four feldspars in K-feldspar and plagioclase: Sample 1 (S1) = pearl gneiss, Sample 2 (S2) = coarse-grained gneiss, Sample 3 (S3) = Weinsberg granite, Sample 4 (S4) = ultramylonite. Stoichiometric feldspar formulae and single feldspar components presented in the lower part of the table were computed assuming 16 oxygen atoms per unit cell.

\begin{tabular}{|l|c|c|c|c|c|r|r|r|}
\hline & \multicolumn{4}{|c|}{ K-feldspar } & \multicolumn{4}{|c|}{ Plagioclase } \\
\hline & $\mathbf{S 1}$ & $\mathbf{S 2}$ & $\mathbf{S 3}$ & $\mathbf{S 4}$ & $\mathbf{S 1}$ & $\mathbf{S 2}$ & $\mathbf{S 3}$ & $\mathbf{S 4}$ \\
\hline $\mathrm{SiO}_{\mathbf{2}}$ & 64.51 & 65.23 & 65.85 & 66.13 & 62.92 & 62.94 & 61.55 & 61.73 \\
$\mathbf{A l}_{\mathbf{2}} \mathbf{O}_{\mathbf{3}}$ & 18.68 & 18.35 & 20.42 & 16.92 & 23.42 & 23.27 & 24.33 & 23.88 \\
$\mathbf{C a O}$ & 0.05 & 0.02 & 0.19 & 0.15 & 5.03 & 4.95 & 4.84 & 4.87 \\
$\mathbf{K}_{\mathbf{2}} \mathbf{O}$ & 15.60 & 15.16 & 7.52 & 15.12 & 0.35 & 0.43 & 0.36 & 0.26 \\
$\mathrm{Na}_{\mathbf{2}} \mathbf{O}$ & 0.70 & 0.87 & 6.08 & 0.65 & 8.54 & 8.52 & 8.71 & 8.69 \\
total & $\mathbf{9 9 . 5 4}$ & $\mathbf{9 9 . 6 3}$ & $\mathbf{9 9 . 7 6}$ & $\mathbf{9 9 . 9 7}$ & $\mathbf{1 0 0 . 2 6}$ & $\mathbf{1 0 0 . 1 1}$ & $\mathbf{9 9 . 7 9}$ & $\mathbf{9 9 . 4 3}$ \\
\hline $\mathbf{S i}$ & 5.980 & 6.020 & 5.896 & 6.066 & 5.550 & 5.560 & 5.470 & 5.500 \\
$\mathbf{A l}$ & 2.040 & 1.990 & 2.152 & 1.923 & 2.440 & 2.420 & 2.550 & 2.510 \\
$\mathbf{C a}$ & 0.006 & 0.001 & 0.016 & 0.011 & 0.480 & 0.470 & 0.460 & 0.470 \\
$\mathbf{K}$ & 1.849 & 1.784 & 0.861 & 1.843 & 0.040 & 0.050 & 0.020 & 0.030 \\
$\mathbf{N a}$ & 0.123 & 0.170 & 1.054 & 0.154 & 1.480 & 1.490 & 1.510 & 1.500 \\
total & $\mathbf{9 . 9 9 8}$ & $\mathbf{9 . 9 4 5}$ & $\mathbf{9 . 9 7 9}$ & $\mathbf{9 . 9 9 8}$ & $\mathbf{9 . 9 9 0}$ & $\mathbf{9 . 9 9 0}$ & $\mathbf{1 0 . 0 1 0}$ & $\mathbf{1 0 . 0 1 0}$ \\
\hline Orthoclase & $\mathbf{0 . 9 3 5}$ & $\mathbf{0 . 9 1 3}$ & $\mathbf{0 . 4 4 6}$ & $\mathbf{0 . 9 2 6}$ & $\mathbf{0 . 0 2 0}$ & $\mathbf{0 . 0 2 5}$ & $\mathbf{0 . 0 1 0}$ & $\mathbf{0 . 0 1 5}$ \\
Albite & $\mathbf{0 . 0 6 2}$ & $\mathbf{0 . 0 8 6}$ & $\mathbf{0 . 5 4 6}$ & $\mathbf{0 . 0 6 4}$ & $\mathbf{0 . 7 4 0}$ & $\mathbf{0 . 7 4 1}$ & $\mathbf{0 . 7 5 9}$ & $\mathbf{0 . 7 5 0}$ \\
Anorthite & $\mathbf{0 . 0 0 3}$ & $\mathbf{0 . 0 0 1}$ & $\mathbf{0 . 0 0 8}$ & $\mathbf{0 . 0 1 0}$ & $\mathbf{0 . 2 4 0}$ & $\mathbf{0 . 2 3 4}$ & $\mathbf{0 . 2 3 1}$ & $\mathbf{0 . 2 3 5}$ \\
\hline
\end{tabular}

with a variable number of dark and bright stripes, K-feldspar is either simple-twinned or untwinned. As demonstrated by feldspar rocks sampled at the southwestern margin of the Bohemian Massif in Austria, feldspar frequently forms the dominant mineral phase in granitic rocks, whereby large feldspar crystals (up to $10 \mathrm{~cm}$ in size) are commonly embedded in a matrix that is produced by the remaining mineral phases (that is, biotite, quartz, plagioclase, etc.). Under high-grade metamorphic conditions, K-feldspar is subject to specific transformation processes resulting, for example, in the formation of sillimanite, garnet, or albite and quartz. During retrograde metamorphic conditions occurring because of the uplift and cooling of the lithological unit, K-feldspar often undergoes a typical decomposition process (Formula 1) that leads to the production of fine symplectitic textures known as myrmekites. Because of their many shapes and sizes, such myrmekites might represent an interesting field for extensive microscopic analysis. Because all factors controlling feldspar formation and decomposition are not fully understood yet, the mineral will still be an object of mineralogical interest in the future.

\section{References}

[1] WA Deer, RA Howie, and J Zussman, An Introduction to the Rock-Forming Minerals, Longmans Scientific and Technical, London, 1992.

[2] TFW Barth, Feldspars, Wiley-Interscience, New York, 1969.

[3] I Parsons, Feldspars and their reactions (proceedings of the NATO Advanced Study Institute on Feldspars and their Reactions), Kluwer, Dordrecht, The Netherlands, 1994.

[4] R Sturm, Microscopy Today 16(5) (2008), 30-36.

[5] G Frasl and F Finger, Beihefte zum European Journal of Mineralogy 3 (1991), 23-40.

[6] R Sturm, Geologisch-petrographische Bearbeitung eines cordieritführenden Mylonits und seiner Umrahmung im Bereich des Pfahls, oberösterreichisches Moldanubikum, University of Salzburg, 1995.
[7] AJ Barker, Introduction to metamorphic textures and microstructures, Blackie, Glasgow and London, 1990.

Minus $\boldsymbol{K}^{\ominus}$ Technology's Negative Stiffness vibration isolators have been selected for ground testing of the James Webb Space Telescope (JWST).

\section{Why have over 2,000 scientists in 35 countries selected Minus $\mathbf{K}^{\circledR}$ vibration isolators?}

Our Negative Stiffness systems deliver $10 x$ to $100 x$ better

performance than air systems and even better than active systems.

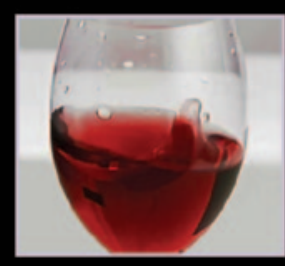

Without Minus $\mathrm{K}^{\circ}$

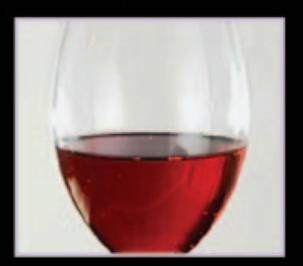

With Minus $\mathrm{K}^{\odot}$
The best performance and the lowest price. That's hard to beat!

\section{minus K TECHNOLOGY}

460 S. Hindry Ave., Unit C, Inglewood, CA 90301 Tel: 310-348-9656 Fax: 310-348-9638 sales@minusk.com • www.minusk.com 


\section{Side-By-Side Comparison? Difficult When Our Coaters Stand Alone.}

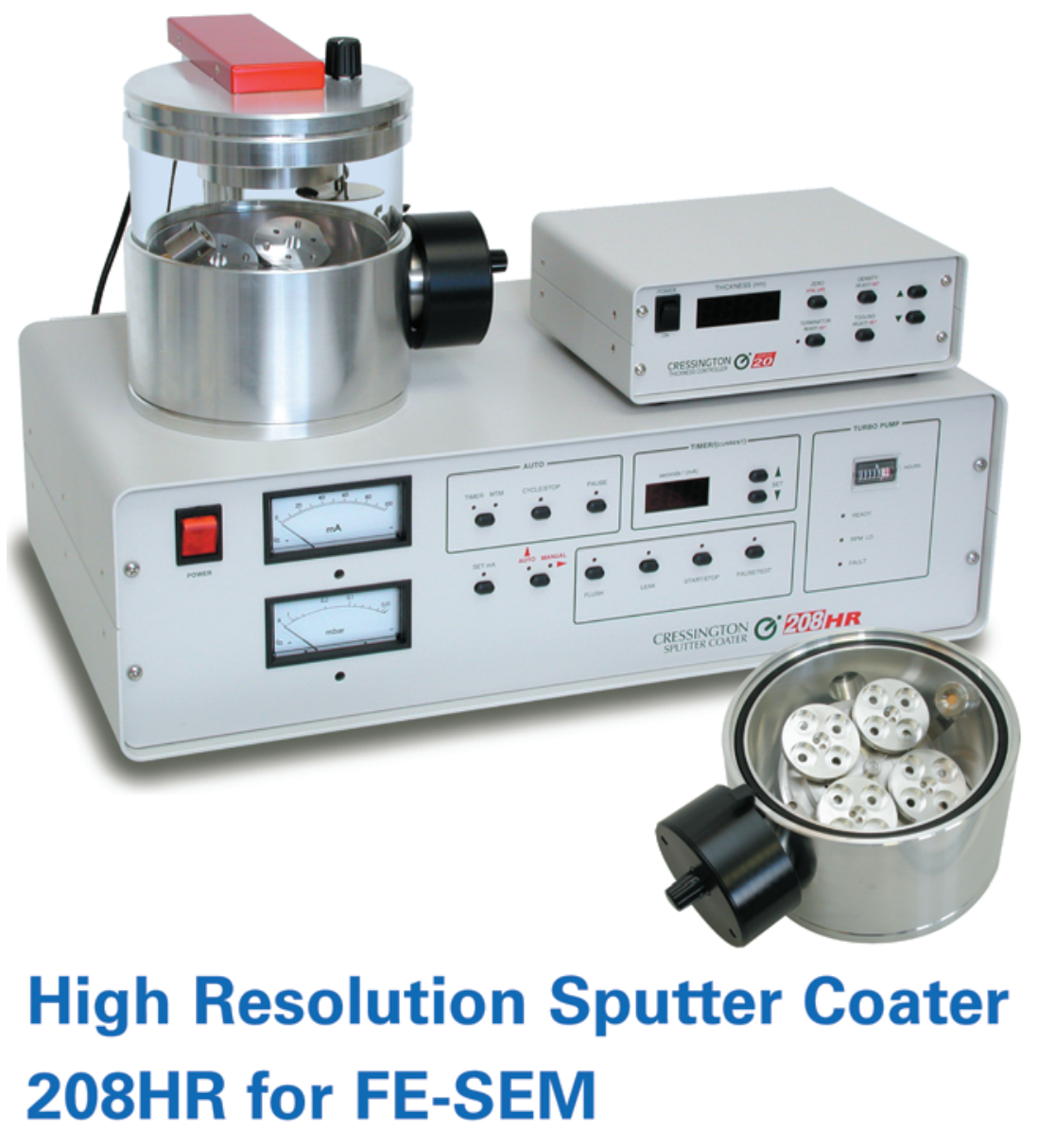

Superior Features:

- High Resolution Fine Coating

- Wide Choice of Coating Materials

- High Resolution Thickness Control

- Multiple Sample Stage Movements

- Wide Range of Operating Pressures

- Compact, Modern, Benchtop Design
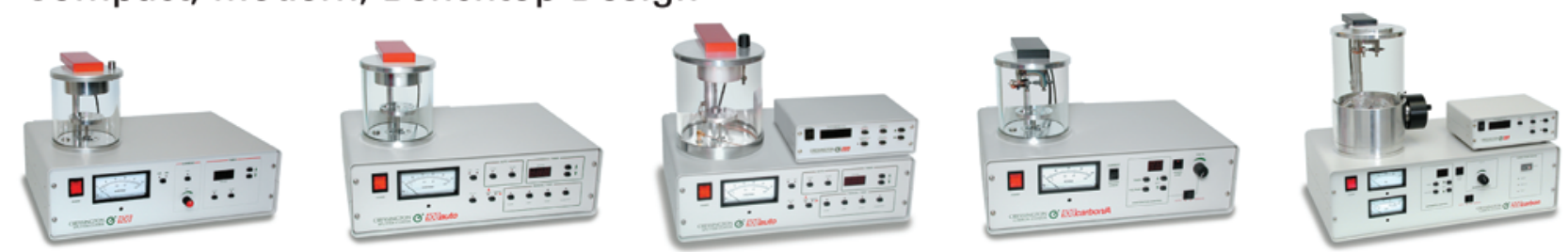

Find out about our complete line of sample coaters. 